
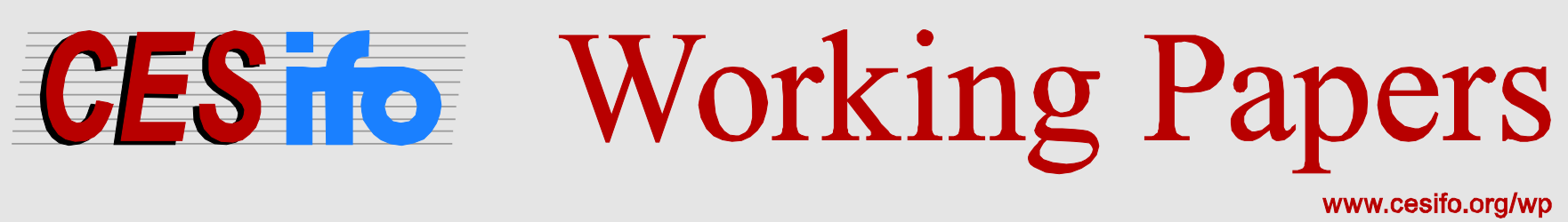

\title{
Home Ownership and Household Portfolio Choice
}

\author{
Thomas Michielsen \\ Remco Mocking \\ Sander van Veldhuizen
}

CESIFO WORKING PAPER NO. 5705

CATEGORY 13: BEHAVIOURAL ECONOMICS

JANUARY 2016

An electronic version of the paper may be downloaded

- from the SSRN website:

- from the RePEc website:

wWw.SSRN.com

www.RePEc.org

- from the CESifo website:

www.CESifo-group.org/wp 


\title{
Home Ownership and Household Portfolio Choice
}

\begin{abstract}
We study the effect of home equity and indebtedness on financial portfolio choices of Dutch households during the period 2006-2012. Using a large administrative dataset at the household level we estimate how home equity and the outstanding mortgage amount influence the share of liquid assets held in stocks. We apply different econometric methods to take selection and endogeneity into account. In our preferred specifications both home equity and the household's amount of mortgage debt have a non-significant impact on the risky asset share.
\end{abstract}

JEL-codes: G110, D140, R310.

Keywords: portfolio choice, house price shocks.

Thomas Michielsen

CPB Netherlands Bureau for

Economic Policy Analysis

P.O. Box 80510

The Netherlands - 2508 GM Den Haag

t.o.michielsen@cpb.nl

Remco Mocking

CPB Netherlands Bureau for

Economic Policy Analysis

P.O. Box 80510

The Netherlands - 2508 GM Den Haag

r.mocking@cpb.nl
Sander van Veldhuizen CPB Netherlands Bureau for Economic Policy Analysis

P.O. Box 80510

The Netherlands - 2508 GM Den Haag

s.van.veldhuizen@cpb.nl

January 13, 2016 


\section{Introduction}

For most homeowners housing is the most important component of household consumption. Recent estimates by CBS Statistics Netherlands indicate that in the lowest income groups housing costs account for 39 percent of total spending, versus 24 percent for the highest income groups. ${ }^{1}$ At the same time, houses are the largest asset owned by most households, and thus the dominant asset in the portfolio. CBS Statistics Netherlands report that residential housing constitutes about 57 percent of Dutch households' overall gross wealth.

The investment in owner-occupied housing induces strongly unbalanced portfolios. Young and middle-aged homeowners hold portfolios which are (strongly) tilted towards housing capital. This potentially puts forward two types of risk. First, when financing the house with a mortgage this creates a risk of leverage. Second, the illiquid nature of housing wealth may constrain households' decision to rebalance their portfolio. While young and middle-aged households invest a major part of their wealth into housing, only one fifth ${ }^{2}$ of Dutch households participated in the stock market in 2012. The average share of liquid financial wealth invested in stocks was about 10 percent.

These observations lead to two natural questions. The first is whether the observed portfolio shares of housing and stocks are optimal from a portfolio diversification point of view. The second is whether the portfolio shares of stocks and housing are driven by typical Dutch institutions. Tax subsidies on home ownership, such as the mortgage interest deductability, make it unattractive for households to separately choose the level of housing consumption and investment. Because of these tax incentives, a majority of Dutch households owns a house at some point during their life-cycle. Home ownership creates a binding housing constraint which affects the financial portfolio choice of many Dutch households. Since the share of housing wealth in total net wealth changes during a typical life-cycle, housing affects the financial portfolio in a way that is not predicted by standard portfolio models. When analyzing the driving factors of households' financial portfolio choices, housing should be taken directly into account. In addition to that, high mandatory pension savings in the Netherlands limit the discretionary savings possibilities of Dutch households as well. These high pension savings also indirectly expose Dutch households to fluctuations in the stock market.

\footnotetext{
${ }^{1}$ See CBS Statistics Netherlands Press release July 9, 2015

${ }^{2}$ See CBS Statistics Netherlands Statline
} 
The related literature is both theoretical and empirical. The theoretical literature takes stock of two mechanisms predicting that housing generally reduces the demand for risky assets, and one mechanism predicting the opposite effect. The illiquid nature of housing and hedging of house price risk generally reduce the demand for risky assets of households (Grossman \& Laroque, 1990; Flavin \& Yamashita, 2002). The opposite effect is the following: investors owning a house substitute home equity (defined as property value minus the current outstanding mortgage amount) for risky stocks to take advantage of the diversification benefit afforded by the low correlation between stock returns and housing returns (Yao \& Zhang. 2005). In the Netherlands this opportunity is enhanced by the deductibility of mortgage interest and is more attractive for wealthy households for whom a leveraged position in housing does not necessarily induce a highly risky position. By contrast, empirical studies find no systematic relationship between housing and stockholding (Fratantoni, 1998; Heaton \& Lucas, 2000; Yamashita, 2003: Cocco, 2005).

In this paper we estimate the impact of mortgage debt and home equity on stock portfolio shares. Home equity and mortgage debt may have two distinct effects on stock portfolio shares. First, home equity increases total wealth enabling households to increase risk exposure. Therefore, home equity may have a non-negative effect on stock holdings. Second, households with a higher mortgage are more likely to fall into negative net wealth because house price fluctuations constitute a form of background risk. Since negative net wealth creates a potential barrier to moving, households with a high mortgage may be more conservative in their financial portfolio decisions to guard against a simultaneous drop in stock and house prices. As such, mortgage debt may have a negative effect on stockholding.

Identification of the causal effect of housing on portfolios faces two methodological challenges. A first challenge is a selection problem originating from the observation that many households do not own stocks at all. Moreover, the decision to participate in the stock market is not random conditional on observed characteristics. Second, there is a potential endogeneity problem when unobserved factors influence both housing and stock shares. We estimate different econometric models dealing with the problems of selection and endogeneity. To control for selection we use Tobit and Heckman type selection models. To tackle the problem of endogeneity we apply an instrumental variable approach comparable to Chetty \& Szeidl (2010).

The main contribution of this paper is that it combines several administrative datasets from CBS Statistics Netherlands to estimate the effect of 
housing on portfolio composition. We construct a household level panel dataset including information on household assets, liabilities, mortgages, property values, and demographic characteristics over the period 20062012. The data allows us to disentangle the effects of home equity and mortgage debt on the risky asset share of households, while controlling for a broad set of household characteristics.

In our preferred specifications both home equity and the household's amount of mortgage debt have a non-significant impact on the risky asset share. This contrasts the conclusions from similar studies in the US and France. We believe that the non-significant results can be explained by (i) the lower stock holding rates in the Netherlands and (ii) the specific Dutch institutional setting where the investment aspect of owning a house is less salient as a result of strong tax incentives for home ownership as well as large and mandatory pension savings.

The remainder of this paper is organized as follows. The next section discusses the related literature. Section 3 explains the identification strategy in more detail. Then, in Section 4 we describe our data and present descriptive statistics. Section 5 present our empirical results. Section 6 concludes.

\section{Related Literature}

We review the most relevant theoretical and empirical literature on homeownership, property value and households portfolio composition. Various theoretical models predict that households having a large share of their wealth invested in housing generally tend to hold smaller shares of their wealth in financial risky assets, such as stocks. The literature highlights three mechanisms through which investment decisions in housing affect portfolio choice. The first mechanism is illiquidity of the house. The model of Grossman \& Laroque (1990) predicts that if it is costly to adjust the level of an illiquid durable consumption good, then households are more risk-averse after the purchase of a durable consumption good such as a house. The second mechanism is hedging housing price risk, meaning that variations in residential property prices affect the risk level of a homeowners portfolio. Flavin \& Yamashita (2002) show that the housing constraint can have an enormous effect on the risk-return trade-off available to the household. As a result, Flavin \& Yamashita (2002) find that highly leveraged homeowners should hedge housing price risk by holding fewer risky financial assets. Sinai \& Souleles (2005) document that for homeowners who are expecting to move up the housing ladder it may be 
optimal to accumulate housing wealth as hedge against housing price risk, though others argue that idiosyncratic house price risk is large compared to the aggregate risk (Case \& Shiller, 1989: Englund, Hwang \& Quigley, 2002). The last mechanism is diversification. Yao \& Zhang (2005) show that when investors are indifferent between renting and owning a house, then investors who own a house will choose a substantially different portfolio allocation than investors renting house services. Investors owning a house substitute home equity for risky stocks, but hold a higher equity proportion in their liquid financial portfolio to take advantage of the diversification benefit afforded by the low correlation between stock returns and housing returns.

The empirical literature on the link between home-ownership and household portfolio choice mostly focuses on the impact of housing decisions on financial wealth decisions. From this literature there are two important take-aways. First, the empirical literature, with a few exceptions, is dominated by U.S. studies either using the Survey of Consumer Finances (SCF) or the Panel Study of Income Dynamics (PSID). Secondly, from the empirical literature two econometric problems emerge, namely a potential endogeneity problem of the key explanatory variables and sample selection issue. In section 3 we discuss in more detail our identification strategy and how we deal with these econometric problems.

To estimate the relationship between housing and financial portfolio most studies explain the share of risky assets in the financial portfolio from housing related variables, such as house value over net wealth, nethousing equity etc. Using the 1989 Survey of Consumer Finances (SCF) Fratantoni (1998) finds that households with a high mortgage expensesto-income ratio tend to hold a smaller share of their financial wealth in the form of risky assets. Yamashita (2003) estimates, using the same data, the theoretical model of Flavin \& Yamashita (2002) and finds that house value-to-net wealth ratio has a negative effect on the share of risky assets of all financial assets after controlling for income, age, family size, education, and a proxy for risk aversion. Yamashita (2003) does not control for the level of net wealth, which makes the results difficult to interpret.

In related work, Heaton \& Lucas (2000), Cocco (2005), and Yao \& Zhang (2005) show that the stock share is positively associated with mortgage debt.These studies use cross-sectional OLS regressions, in which property value is included as a covariate, and the PSID data. Shum \& Faig (2006) study what factors explain the stock market participation decision and the share of stocks of household financial wealth. They control for housing investment using two variables. They do not obtain a significant estimate of real estate exposure on stock holdings, using the Survey of Consumer 
Finances.

Not all of the above studies take the effects of the renting versus owning decision on portfolio allocation into account. Yao \& Zhang (2005) show, using the PSID data, that renters and homeowners' portfolio choices have different determinants and react differently to key variables such as the net worth income ratio and investor age. Kullman \& Siegel (2005) also use the PSID data and find that homeowners are more likely to participate in the stock market than renters. Among homeowners, higher levels of housing investment decrease the share of financial assets invested in stocks, whereas again higher mortgage holdings relative to net wealth increase the share. Using Dutch Collective Bank Study-data, Hochguertel \& van Soest (2001) also find that demand for financial wealth is systematically different for renters and homeowners among Dutch households. Furthermore, they find evidence that investing in financial wealth involves a positive threshold which has to be overcome before positive financial asset holdings are possible. Moreover, this threshold is magnified by the level of housing investment. This finding corresponds with the theoretical finding that housing investment crowds out financial investment.

Chetty \& Szeidl (2010) study the effect of home equity and mortgage debt on portfolio shares. They distinguish between home equity wealth and mortgage debt, as they have opposite-signed effects on portfolio choice. Using data from the Survey of Income and Program Participation they find that increases in property value (holding home equity constant) reduce stockholding significantly, while increases in home equity wealth (holding property value constant) raise stockholding. Fougere \& Poulhes (2012) replicate Chetty \& Szeidl (2010) using data on French households and confirm that mortgage debt and home equity have significant, opposite-signed, effects on portfolio shares.

To summarize, theory predicts that housing substantially impacts portfolio choice because investment in housing increases a household's exposure to risk and illiquidity. Empirical studies, however, have not found a systemic relationship between housing and portfolios in practice.

\section{Estimation Strategy}

The central equation in the literature that is concerned with estimating the effect of owner-occupied housing on portfolio choices is of the form:

$$
s_{i t}=\alpha+\beta h_{i t}+\gamma \mathbf{X}_{i t}+\epsilon_{i t}
$$


In equation 1, $s_{i t}$ denotes the share of stocks as a percentage of the total liquid assets of household $i$ in year $t$. The independent variables of interest, $h_{i t}$, are proxies for the value of the house and the outstanding mortgage debt. We include both home equity (defined as property value minus outstanding mortgage debt) and the outstanding mortgage debt as we expect opposite-signed effects on the risky asset share.

We use variation across regions and variation over time to disentangle the effects of home equity and outstanding mortgage debt on portfolio choices. By comparing households who bought similar houses in different regions at the same price level, we are able to estimate the effect of home equity holding mortgage debt constant - if prices develop differently in the two regions. Similarly we can estimate the effect of outstanding mortgage debt holding home equity constant by comparing households who bought their houses at a different price level while they experienced the same price increase.

Chetty \& Szeidl (2010) include home equity and the property value instead of outstanding mortgage debt. This is equivalent to our approach: controlling for home equity, property value and mortgage debt both proxy the outstanding debt. For ease of interpretation, we choose to include the latter. Yamashita (2003) uses the ratio of the house value and total net worth of the household. The vector $\mathbf{X}_{i t}$ includes all kind of background characteristics of the household, such as household composition, age, (disposable) income, and the main source of income.

When estimating equation 1, the econometrician faces two main problems. First, many households do not own stocks at all and the decision to participate in the stock market is not random conditional on observed characteristics. In other words, there is a selection problem. Second, there is a potential endogeneity problem when unobserved factors influence both the variable of interest, $h_{i t}$ and the dependent variable $s_{i t}$. In that case the estimate for the coefficient $\beta$ is biased. Below we discuss how we deal with these two issues.

\subsection{Selection}

The dependent variable $s_{i t}$ is a continuous variable, but for a large part of the households its value equals 0 . The type I Tobit model introduces a latent variable $s_{i t^{*}}$ to model this type of dependent variable. Formally, the 
standard Tobit model is given by:

$$
\begin{aligned}
& s_{i t}^{*}=\alpha+\beta h_{i t}+\gamma \mathbf{X}_{i t}+\epsilon_{i t} \\
& s_{i t}=s_{i t}^{*} \text { if } s_{i t}^{*}>0 \\
& =0 \quad \text { if } \quad s_{i t}^{*} \leq 0
\end{aligned}
$$

The standard Tobit model does not allow variables to have a different effect on the decision to participate than on the stock share conditional on participation.

One solution to this problem is to estimate a two-stage Heckman model (Heckman, 1979), which first estimates the selection process (stocks or no stocks?) and then the decision process conditional on participation (how many stocks?). The Heckman model is given by (3), where $p_{i t}$ is a binary variable indicating whether a household owns stocks or not.

$$
\begin{aligned}
s_{i t}^{*} & =\alpha+\beta_{1} \mathbf{X}_{1 i t}+\epsilon_{1 i t} \\
p_{i t}^{*} & =\alpha+\beta_{2} \mathbf{X}_{2 i t}+\epsilon_{2 i t} \\
s_{i t}=s_{i t}^{*} p_{i t} & =1 \quad \text { if } p_{i t}^{*}>0 \\
s_{i t} \text { not observed, } p_{i t} & =0 \quad \text { if } p_{i t}^{*} \leq 0 \\
\epsilon_{1 i t} & \sim N(0,1), \epsilon_{2 i t} \sim N\left(0, \sigma^{2}\right), \operatorname{corr}\left(\epsilon_{1 i t}, \epsilon_{2 i t}\right)=\rho
\end{aligned}
$$

The Heckman model assumes that the error terms of the two stages are jointly normally distributed. Moreover, to correct for sampling selectivity, one should include at least one variable in the selection equation which is not included in the second-stage regression. For instance, Fagereng, Gottlieb \& Guiso (2013) assume that the decision to participate is influenced by the lagged value of overall lifetime wealth, while lifetime wealth is not related to the conditional portfolio share $3^{3}$ This assumption stems from the idea that stock market participation is associated with fixed costs, e.g. of opening a stock account and gathering information about suitable stocks. The benefits from participation are proportional to wealth, so it makes more sense for wealthier individuals to pay the fixed costs.

It is not clear whether the Heckman exclusion restriction or the Tobit equality restriction on the coefficients in the participation and outcome equation is preferable (Puhani, 2000). Grinblatt, Koloharju \& Linnainmaa (2011) report that wealthier individuals hold more risky portfolio's conditional on participation, casting doubt on the exclusion restriction in

\footnotetext{
${ }^{3}$ This is predicted by the CAPM model.
} 
Fagereng et al. (2013). At the same time, any positive fixed cost of stockholding is likely to generate a discrepancy in the relative influence of covariates on the participation and outcomes decisions, which is at odds with the Tobit model's assumption these relative effects are the same. We will present results for both models, although we cannot estimate a Heckman model that both corrects for the endogeneity of homeownership and has correct standard errors, because of computational issues.

\subsection{Endogeneity}

The main endogeneity concern is that there are unobserved factors influencing both the variable of interest, $h_{i t}$ and separately the dependent variable $s_{i t}$. One example is future labor income of households (Cocco, 2005). Households with a higher expected future income are more likely to buy larger houses and might also be willing to invest a larger share of their financial wealth in stocks.

We deal with this problem by implementing an instrumental variable (IV) approach. A valid instrument is correlated with $h_{i t}$ and only affects the stock share $s_{i t}$ through $h_{i t}$. Chetty \& Szeidl (2010) include both property value and home equity in their model, meaning that $h_{i t}$ is a vector of two variables in their set-up. They propose to use the regional house price index in individual $i$ 's region in the current year $(t)$ and in the year that he bought the house as instruments for $h_{i t}$. The coefficients that determine the effect of home equity and mortgages on stockholding are then determined by changes in regional house prices since the year of purchase, and not by possibly endogenous decisions regarding the individual's own home equity and outstanding mortgage such as paying down the mortgage, taking out a second mortgage or investments in home improvements.

Regional house prices indices must be sufficiently correlated with individual home equity and mortgage amounts to be suitable. We use house price indices at the COROP-level ${ }^{4}$ The correlation coefficient between the current regional house price index and the current individual house value in our estimation sample is 0.119 . We include first-stage results for our instrumental variable regressions in section 5 .

The validity of this instrument requires that changes in regional house prices are orthogonal to all other factors that affect household portfolio decisions 5 Regional house price indices may be correlated with portfo-

\footnotetext{
${ }^{4}$ The Netherlands is divided into 40 COROP areas and house price developments differ significantly between these areas, as we illustrate in Figure 1 in the Appendix.

${ }^{5}$ When we include year, region and year-of-purchase fixed effects as well as cohort
} 
lio choice through other channels than the amounts of home equity and outstanding mortgage if regional house prices are correlated with other factors that directly influence portfolio choice, such as macroeconomic circumstances. Following Chetty \& Szeidl (2010), we deal with this problem by including the regional unemployment rate in the current year and the year of purchase, to control for macroeconomic conditions.

Moreover, selection effects could play a role if the decision to buy a house at a given price level is related to non-observed household characteristics, for example if individuals who buy homes when prices in their region are high are more risk-tolerant. We attempt to mitigate this selection effect by including controls that are correlated with risk preferences: education of the household head and main source of household income (which distinguishes among others between public sector jobs, private sector jobs and entrepreneurship). Unfortunately, we do not observe risk preferences directly in our dataset. Chetty \& Szeidl (2010) argue that omitted variable bias due to risk preferences would bias the results against the hypothesis that individuals with higher mortgages have safer financial portfolios.

\subsection{Estimation techniques}

As a benchmark, we estimate a Tobit model that corrects for selection but not for endogeneity, as well as a two-stage least squares (2SLS) model that accounts for endogeneity but not for selection.

As our preferred specification, we estimate a Tobit model with endogenous regressors and model the first stage regression for the mortgage amount as a Tobit specification as well. The reason for doing so is that the outstanding mortgage amount of both renters and a high share of the older homeowners equals zero. We show that this modification has a large impact on the estimated coefficients. Since this is a fully observed recursive system of seemingly unrelated equations, the coefficient estimates are consistent (Roodman, 2011). Although there is bunching at zero as well for the home equity variable (because of no-amortization mortgages and renters), it is more complicated to use limited dependent variable techniques in the IV equation for home equity because a sizeable number of households has

controls, these instruments capture the effect of a household's home equity on stock market participation that is orthogonal to cohort, year, regional and year-of-purchase effects. For example, our approach controls for the notion that home buyers in Amsterdam may have different risk attitudes compared to home buyers in more rural areas, or that risk attitudes differ between individuals that bought their homes in 1995, when home prices were relatively low across the Netherlands, versus 2005. 
negative home equity. Our approach refines the methodology of Chetty \& Szeidl (2010), who estimate a Tobit model but use a linear specification for the mortgage amount ${ }^{6}$ Still, it does not allow variables to have a different impact on the decision to participate than on the stock share conditional on participation as in the Heckman approach.

Further, we perform two estimations that deal with selection and endogeneity sequentially. In the first, we first tackle the selection problem by estimating a Probit equation for the stock market participation decision in which we do not instrument for home equity and the outstanding mortgage. We use the resulting inverse Mills ratio as a control variable in a two-stage least squares model on the subsample of households that has a positive stock share. In the second approach, we first deal with the endogeneity problem. We estimate the predicted value of $h_{i t}$ using OLS and then include the predicted values $\hat{h_{i t}}$ in a Heckman selection model. By doing so, standard errors are underestimated, because uncertainty about the first stage regression is not taken into account in the second-stage regressions. The advantage is that under this approach variables are allowed to have a different effect on the decision to participate than on the stock share conditional on participation. This approach follows Yamashita (2003).

Appendix B gives a technical overview of the different models that we estimate.

\subsection{Hypotheses}

In line with the discussion of the theoretic literature in section 2, we expect opposing effects of home equity and the mortgage amount on the stock percentage of financial assets. Controlling for home equity, we expect a negative effect of outstanding mortgage debt on stock holdings. A mortgage constitutes a commitment that must be repayed when the household sells the house. Because households with moderate to high loan-to-value ratios are highly leveraged in the housing part of their portfolio, we expect them to have a lower stock percentage. Holding the mortgage amount fixed, an increase in home equity increases total wealth. This enables the household to take more risks if it has decreasing absolute risk aversion, for example because its utility function features a subsistence level of consumption (Calvet \& Sodini, 2014). We thus expect a positive influence of home equity on stock holdings.

Hypothesis 1 The stock percentage is negatively related to the outstanding mortgage value.

\footnotetext{
${ }^{6}$ We report results for Chetty \& Szeidl (2010)'s approach as well.
} 
Hypothesis 2 The stock percentage is positively related to the amount of home equity.

\section{Data}

We use administrative data on household assets, liabilities, mortgages, house values and demographic characteristics from Statistics Netherlands for 2006-2012. For computational reasons we take a random sample of $10 \%$ of Dutch households. We construct this sample using the German Household Panel Study sampling methodology (Kroh, Pischner, Spieß \& Wagner, 2008). The data on assets excluding house values and mortgages originate from the Dutch Tax and Customs Administration, based on individual tax returns and information on savings and stock accounts that banks provide to the Tax and Customs Administration. We observe three financial asset categories: stock holdings, bonds and savings.7] Non-financial assets include moveable properties and second homes. The data on debt distinguishes between mortgage debt and other types of debt. All household balance sheet data relate to January 1 of a year; household income data relate to the entire preceding year. We convert monetary values using a CPI from Statistics Netherlands with base year 2006.

Unfortunately, we do not observe a household's mortgage type. As a consequence of fiscal incentives, many households in our sample period have a mortgage with an associated savings or stock account $(47.2 \%$ in $2006^{8}$. These households do not amortize their mortgage, but accumulate savings in a tax-exempt account that will be used to pay off the mortgage in one go. We have no information on the balance of these associated accounts. We cannot observe which households have capital built up in an associated account, because of data quality issues and since we cannot distinguish mortgages with an associated account from no-amortization mortgages, which also enjoy a significant market share. For lack of a good way to identify which households have an associated account, following Struyven (2015) we randomly select $47.2 \%$ of homeowners and estimate the capital built up in their associated accounts using a standard amorti-

\footnotetext{
${ }^{7}$ We exclude stakes of more than 5 per cent in individual companies from both stock holdings and financial wealth. These holdings typically belong to (part-) owners or senior partners of small- and medium-sized enterprises and are very concentrated among a small group. These assets are illiquid, their value may be hard to estimate and the focus of this paper is on publicly traded stocks.

8Source: Dutch Insurers' Association, https://www.verzekeraars.nl/ verzekeringsbranche/statistieken/Documents/VerzekerdVanCijfers/vvc2013.pdf
} 
zation formula. We also correct mortgage values that seem highly unlikely and probably result from administrative errors..$^{9}$ We use the administrative house values determined by Dutch municipalities (WOZ-values) The WOZ-values are assessed using home characteristics and sale prices of homes in the neighborhood, and used for the property tax base. These administrative prices correlate well with market values (CBS, 2014).

We track households over time if the household head and his/per partner, as identified by the Statistics Netherlands data, are the same in all sample years and if there are no composition changes other than newborn children or children leaving the home. We define the household head as the partner with the highest income. Our demographic characteristics include the main source of household income (employment in the private or public sector, benefits, pension, self-employment, wealth or other), age of the household head, household size and the highest completed education of the household head.

We drop households with adult members who are not related to each other as part of a couple or as parent and child, because these households (such as friends living together) may have largely separate financial arrangements. We exclude households who moved between 2006 and 2012, as well as households who leave the sample (for example because they move abroad or passed away). We also drop households whose financial wealth or home equity is below the 1st percentile or above the 99th percentile, as well as households whose mortgage or stock percentage is above the 99th percentile.

As shown in Table 1 in Appendix A these selection criteria reduce the sample size by slightly over a half of the original sample size. Because we only include households between age 25 and 80 and households who do not move, households in the youngest age category are under represented in the analysis sample. Although this introduces selection effects in our estimation sample, the selection criteria need to be applied for a clean identification. The reason is that events such as moving or divorce have potentially large effects on both home values and liquid financial assets.

In the robustness section, we present a separate analysis on a subsample of households with a household head below age 61, to account for the possibility that households make significant changes in their financial portfolio around the retirement age. In this analysis we also include pension entitlements of the household head as a control variable. We also

\footnotetext{
${ }^{9}$ For many households, the mortgage value is exactly the same or similar in years $t-1$ and $t+1$, but zero or $90 \%$ smaller in the intermediate year $t$.

${ }^{10}$ After the Dutch law 'Wet Waardering Onroerende Zaken'.
} 
perform a robustness check in which we restrict the sample to homeowners, and following Fratantoni (1998), include the predicted value from a probit regression for home ownership.

For measuring human wealth, we follow the method of Cocco, Gomes \& Maenhout (2005): we calibrate a life cycle earnings pattern per income decile, and use this to calculate a household's expected discounted lifetime income ${ }^{11}$ Also analogous to Cocco et al., we estimate the permanent and transitory variance of household income. Together with the household's source of income, these variables control for the uncertainty of a household's income and indirectly for risk preferences. Following Fagereng et al. (2013), we control for cohort effects by including the geometric average MSCI world return during the years when the household head was $18-2512$

Table 2 in Appendix A displays the mean and standard deviation of our main variables for the full sample, the estimation sample ${ }^{13}$ and the sample of stock market participants. There is large variation in stock holdings. About 75 percent of the households does not hold any stocks. The stock market participation rate is slightly higher in the estimation sample $(27 \%)$ compared to the full sample $(23 \%) .14$ The average stock share of financial assets in the whole sample, including nonparticipants, is $9 \%$. Among those with positive stock holdings, the mean risky share is 33\%. On average, stock owners have higher mortgages, while they also have higher levels of financial and human wealth.

Stock participation differs across age groups and between home owners and renters. Figure 2 shows that in 2012 stock participation starts off around $10 \%$ at age 25 , and peaks around $25 \%$ in middle age before declining into retirement. In 2006 participation rates were between 5 and 10 percentage points higher for all ages. Homeowners have much higher participation rates than renters, as can be seen in Figure 3 . Figure 4 shows that especially the middle-aged and older age cohorts decreased their stock market participation during the period 2006-2012. The youngest cohorts increased their participation in the first years of the sample period, while

\footnotetext{
${ }^{11}$ See Appendix C for details.

${ }^{12}$ Before the MSCI world index became available in 1970, we use the S\&P500 for the geometric average.

${ }^{13}$ For computational reasons, we perform the maximum likelihood analyses on a random $25 \%$ subsample of this group.

${ }^{14}$ For households with financial wealth less than the threshold for the Dutch wealth tax (about 20.000 euros), the stock holdings are not observed. If we set the stock holdings for this group equal to zero, our summary statistics for the full sample are in line with aggregate participation rates from Statistics Netherlands, statline.cbs.nl.
} 
they left the stock market with the onset of the financial crisis.

The average home equity of households as a percentage of the property value increases gradually over the life cycle as Figure 5 shows. For the youngest households home equity is on average below 20 percent, indicating that at least 80 percent of the property value is financed through a mortgage. In 2012, after the steep house price decline starting in 2008, home equity has declined compared to 2006 especially for young households. This also becomes very clear from Figure 6, which shows that the average home equity of the youngest cohort declined from about 20 percent in 2006 to just above 0 percent in 2012.

In Figure 7 we turn to the main question of our research and show how home equity correlates with the stock share. For all age categories we observe a similar pattern: homeowners with the lowest home equity have, on average, the highest share of their liquid wealth invested in stocks. This pattern seems to be consistent over time, although the relationship is less clear for the youngest age categories in 2012.

\section{Results}

In the standard Tobit model (see the first column of Table 3), both home equity and mortgage debt have a positive and significant effect on the stock share. The coefficient of 0.0041 indicates that a 10,000 euro increase in home equity, holding the outstanding mortgage constant, increases the intended stock holdings by 0.4 percentage points. Similarly, a 10,000 euro increase in the outstanding mortgage, holding home equity constant, leads to a 0.6 percentage point increase in the intended stock share. Compared to the average conditional stock share of 36 percent, these effects are relatively modest.

By estimating a standard Tobit model we do not take the possible endogeneity of our two independent variables of interest into account. Therefore we estimate IV Tobit models where home equity and the outstanding mortgage amount are instrumented by the regional home price indices in the current year and the year of purchase. The results are presented in the second and third column of Table 3. The instruments have the expected signs in the first stage regressions and are statistically significant in the second stage, except for the current year home price index in the outstanding mortgage regression. In contrast to the standard Tobit regression, home equity and outstanding mortgage are no longer significant in the second stage stock share regression. The instrumental-variable Tobit approach makes it difficult to formally test for weak instruments. We hope to shed 
some further light on the power of the instruments when we discuss the 2SLS estimations. One result that makes us confident about the validity of our instruments is that the point estimate for the second-stage coefficient on the outstanding mortgage in the first column is not contained in the $95 \%$ confidence interval when we instrument for the outstanding mortgage in the second column.

One explanation for this discrepancy is that there are unobserved factors, such as future labour income or an expected inheritance, that cause households to purchase a large house and have a high stock percentage, in which case the standard Tobit coefficients are biased upwards. On the other hand, if risk-seeking households are more likely to purchase a house when regional house prices are high, the mortgage coefficients in the IV regressions are biased downwards if the education level and source of income do not fully capture risk aversion. Besides that, we find that the coefficients in the second column, where the first stage mortgage regression is modeled as Tobit, are more realistic and closer to the original Tobit estimates than the coefficients in the third column. We conclude from this that results could be biased when not taking the censoring at zero of the outstanding mortgage variable into account.

In Table 4 we take a different approach. We start in the first column by only taking the endogeneity problem into account and present the results of a standard 2SLS estimation. Again, we find that the coefficients on home equity and outstanding mortgage are non-significant. In the second column of Table 4 we present the results of a 2SLS estimation on the sample of stock owners and control for selection effects by including the inverse Mills ratio as a regressor ${ }^{15}$. The results are in line with our previous findings. Although the signs of the coefficients on home equity and outstanding mortgage turn negative, we still do not find any significant effects. In the main 2SLS specification, we find a cluster-robust Cragg-Donald F-value of 5.75, which formally rejects the null hypothesis of weak instruments. Because of the clustered standard errors, it is not clear whether we can compare this F-value to common rules of thumb such as the Stock \& Yogo (2005) table (Cameron \& Miller, 2015).

Finally, we estimate two Heckman models where we deal with the endogeneity issue by first estimating predicted values of $h_{i t}$ using our instruments and including the values $\hat{h_{i t}}$ in a Heckman stock share regression (see equation 9 in Appendix B). The two models in the third en fourth column of Table 4 differ in the way the first-stage mortgage regression is

\footnotetext{
${ }^{15}$ In Appendix $B$ we explain how the inverse Mills ratio is calculated
} 
modelled. In both specifications we find a positive effect ${ }^{16}$ of home equity on the stock share conditional on participation. The effect is relatively large compared to our preferred estimate in Table 3. The coefficients of about 0.02 indicate that a 10,000 euro increase in home equity leads to a 2 percentage point increase in the intended stock share. For the outstanding mortgage we also find positive, but much smaller, coefficients. The results in the third and fourth column of Table 4 are more in line with the recent findings of Chetty \& Szeidl (2010) and Fougere \& Poulhes (2012).

\subsection{Robustness}

We have performed a number of robustness checks to check the sensitivity of our results to changes in the sample or econometric models.

We start by estimating the models in Table 3 for the sample of home owners. The reason is twofold. First, home owners and renters are potentially very different groups such that regression coefficients might have different signs or order of magnitude. Second, the model set-up forces to put housing equity and mortgages equal to zero for renters. To control for sample selection bias we include the inverse Mills ratio calculated from a Probit regression of home ownership on the same set of covariates as in our stock share regressions. The results are presented in Table 5 and support our previous findings.

Next, we check whether our findings change when we limit our sample to households below the age of 60 . By doing so we exclude the possibility that our findings are driven by the notion that households change their financial portfolio substantially around the retirement age. The coefficients in Table 6 are again very similar to what we found in our baseline estimates indicating that households below the age of 60 do not respond differently to changes in home equity and outstanding mortgage than the full sample.

Furthermore, we perform a few robustness checks of which the results are not shown in this paper. ${ }^{17}$ Since the education level is only available for a selection of the households, one might be concerned about possible selection effects. Therefore we estimate our models without education fixed effects, but the results are the same as in our baseline specifications.

\footnotetext{
${ }^{16}$ Note that the Heckman estimator we used does not allow for clustering of standard errors. Besides that, standard errors are underestimated since we do not take first-stage uncertainty into account in the second-stage regressions by estimating the IV Heckman model in this naive way. Therefore we do not draw conclusions on the significance of these particular estimates.

${ }^{17}$ The results are available upon request.
} 
We change the definitions of our variables of interest to test whether the way we include home equity and outstanding mortgage matters. Instead of including home equity as a monetary variable, we calculated home equity as a percentage of property value. This new variable does not have a significant impact on the conditional stock share.

We also change the dependent variable by including bonds in the household's risky asset share. The ratio of bonds over total liquid financial assets is very small and including bonds in the dependent variable does not lead to different conclusions.

Next, we estimate our models on different subsets of our sample. First, our results do not change when we split the sample in two equally large groups according to net wealth excluding home equity.

Finally, we do not find different results when we estimate our models for self-employed households and households with a public or private sector job as main source of income separately.

\section{Concluding Remarks}

We study the effect of home ownership on financial portfolio choices of Dutch households during the period 2006-2012. We follow the same strategy as Chetty \& Szeidl (2010) and disentangle the effects of home equity and the outstanding mortgage on the household's risky asset share. Using a large administrative household level dataset, containing information on financial portfolios, home values, income, and a rich set of background characteristics, we find that both home equity and outstanding mortgage have a positive, but non-significant, effect on the stock share.

So far, previous empirical studies have not found a systemic relationship between home ownership and household portfolio choices. In that respect our results are not surprising. However, recent studies by Chetty \& Szeidl (2010) and Fougere \& Poulhes (2012) argue that it is important to separate the effects of home equity and outstanding mortgage on the portfolio composition. Both studies find a positive effect of home equity on the stock share, while the outstanding mortgage is shown to have a negative impact on the share of stock in the financial portfolio of households. We follow the strategy employed in these studies, but we do not find a significant impact of home equity and mortgage amounts on the Dutch household's stock share.

A possible explanation for our finding that home equity and mortgage amounts do not influence the risky asset share of Dutch households is that investing in the stock market is relatively unpopular in the Netherlands 
(25\% in 2004) compared to the US (50\%) and France (43\%) (Christelis, Georgarakos \& Haliassos, 2013). Households in the US tend to be larger and have higher labour market participation, characteristics that are both associated with higher stock holdings. In France, Christelis et al. argue that the defined contribution occupational pension scheme make households more familiar with the stock market, which also has a positive effect on their direct stock holdings. With low average stock shares in the Netherlands, the risky asset share is probably not the first component of the financial portfolio to adjust.

Another possibility is that the investment aspect of owning a home is less important for Dutch households. The Dutch institutional setting is characterized by large pension funds with large mandatory contributions and strong tax incentives for home ownership. In this setting the decision to buy a house is natural for many households as a consequence of these fiscal incentives. Because mandatory pensions are high, owning a house is not seen as an investment to finance consumption after retirement. When the investment aspect of owning a home is less salient, changes in home equity and mortgage amounts might be less important drivers of financial portfolio composition. 


\section{References}

Calvet, L. \& Sodini, P. (2014). Twin picks: Disentangling the determinants of risk-taking in household portfolios. Journal of Finance, 59(2), 867-906.

Cameron, A. \& Miller, D. (2015). A practitioner's guide to cluster-robust interference. Journal of Human Resources, 50(2), 317-372.

Carroll, C. \& Simwick, A. (1997). The nature of precautionary wealth. Journal of Monetary Economics, 40, 41-71.

Case, K. \& Shiller, R. (1989). The efficiency of the market for single-family homes. The American Economic Review, 79(1), 125-137.

CBS (2014). Prijsindex bestaande koopwoningen: Methodebeschrijving. Technical report.

Chetty, R. \& Szeidl, A. (2010). The effect of housing on portfolio choice. NBER Working Paper 15998.

Christelis, D., Georgarakos, D., \& Haliassos, M. (2013). Differences in portfolios across countries: economic environment versus household characteristics. The Review of Economics and Statistics, 95(1), 220-236.

Cocco, J. (2005). Portfolio choice in the presence of housing. Review of Financial Studies, 18(2), 491-533.

Cocco, J., Gomes, F., \& Maenhout, P. (2005). Consumption and portfolio choice over the life cycle. Review of Financial Studies, 18(1), 491-533.

Englund, P., Hwang, M., \& Quigley, J. (2002). Hedging housing risk. Journal of Real Estate Finance and Economics, 24(1-2), 167-200.

Fagereng, A., Gottlieb, C., \& Guiso, L. (2013). Asset market participation and portfolio choice over the life-cycle. Statistics Norway Discussion Papers No. 758.

Flavin, M. \& Yamashita, T. (2002). Owner-occupied housing and the composition of the houshold portfolio. The American Economic Review, 92(1), 345-362.

Fougere, D. \& Poulhes, M. (2012). The effect of housing on portfolio choice: A reappraissal unsing french data. Technical report, CEPR Working Paper 9213. 
Fratantoni, M. (1998). Homeownership and investment in risky assets. Journal of Urban Economics, 44(1), 27-42.

Grinblatt, M., Koloharju, M., \& Linnainmaa, J. (2011). IQ and stock market participation. Journal of Finance, 66(6), 2121-2164.

Grossman, S. \& Laroque, G. (1990). Asset pricing and optimal portfolio choice in the presence of illiquid durable consumption goods. Econometrica, 58(1), 25-51.

Heaton, J. \& Lucas, D. (2000). Portfolio choice and asset prices: The importance of entrepreneurial risk. Journal of Finance, 55(3), 1163-1198.

Heckman, J. J. (1979). Sample selection bias as a specification error. Econometrica, 47(1), 153-161.

Hochguertel, S. \& van Soest, A. (2001). The relation between financial and housing wealth: Evidence from dutch household. Journal of Urban Economics, 49(2), 374-403.

Kroh, M., Pischner, R., Spieß, M., \& Wagner, G. (2008). On the treatment of non-original sample members in the German Household Panel Study (SOEP). Methoden - Daten - Analysen, 2(2), S179-S198.

Kullman, C. \& Siegel, S. (2005). Real estate and its role in household portfolio choice. In EFA 2003 Annual Conference Paper No. 918.

Puhani, P. A. (2000). The Heckman correction for sample selection and its critique. Journal of Economic Surveys, 14(1), 53-68.

Roodman, D. (2011). Fitting fully observed recursive mixed-process models with cmp. Stata Journal, 11(2), 159-206.

Shum, P. \& Faig, M. (2006). What explains househld stock holdings? Journal of Banking and Finance, 30(9), 2579-2597.

Sinai, T. \& Souleles, N. (2005). Owner-occupied housing as a hedge against rent risk. Quarterly Journal of Economics, 120(2), 763-789.

Stock, J. \& Yogo, M. (2005). Testing for weak instruments in linear IV regressions. In D. Andrews (Ed.), Identification and Inference for Econometric Models. Cambridge University Press.

Struyven, D. (2015). Housing lock: Dutch evidence on the impact of negative home equity on household mobility. Technical report, MIT. 
Yamashita, T. (2003). Owner-occupied housing and investment in stocks: an empircal test. Journal of Urban Economics, 53, 220-237.

Yao, R. \& Zhang, H. (2005). Optimal consumption and portfolio choices with risky housing and borrowing constraints. Review of Financial Studies, 18(1), 197-239. 


\section{Appendix A Descriptive Statistics}

Table 1: Age distribution in different samples (standard deviations in parentheses)

\begin{tabular}{lccc}
\hline \hline & Before selection & Sample & Stock owners \\
\hline age 20-30 & 0.11 & 0.02 & 0.01 \\
& $(0.32)$ & $(0.14)$ & $(0.11)$ \\
age 30-40 & 0.18 & 0.15 & 0.15 \\
& $(0.38)$ & $(0.36)$ & $(0.36)$ \\
age 40-50 & 0.21 & 0.24 & 0.27 \\
& $(0.41)$ & $(0.43)$ & $(0.45)$ \\
age 50-60 & 0.19 & 0.19 & 0.21 \\
& $(0.39)$ & $(0.39)$ & $(0.40)$ \\
age 60-70 & 0.15 & 0.22 & 0.22 \\
& $(0.36)$ & $(0.41)$ & $(0.41)$ \\
age 70+ & 0.17 & 0.18 & 0.14 \\
& $(0.37)$ & $(0.38)$ & $(0.35)$ \\
\hline Observations & 4020047 & 1729510 & 462320 \\
\hline \hline
\end{tabular}


Table 2: Summary statistics (standard deviations in parentheses)

\begin{tabular}{|c|c|c|c|}
\hline & Before selection & Sample & Stock owners \\
\hline Stock share & $\begin{array}{c}0.08 \\
(0.19)\end{array}$ & $\begin{array}{c}1 \\
0.09 \\
(0.20)\end{array}$ & $\begin{array}{c}0.33 \\
(0.26)\end{array}$ \\
\hline Stock market participation & $\begin{array}{c}0.23 \\
(0.42)\end{array}$ & $\begin{array}{c}0.27 \\
(0.44)\end{array}$ & \\
\hline Home equity $(10,000 \mathrm{E})$ & $\begin{array}{c}7.97 \\
(11.94)\end{array}$ & $\begin{array}{l}10.26 \\
(12.55)\end{array}$ & $\begin{array}{c}14.89 \\
(14.04)\end{array}$ \\
\hline Outstanding mortgage $(10,000 \mathrm{E})$ & $\begin{array}{c}6.66 \\
(9.99)\end{array}$ & $\begin{array}{c}6.04 \\
(9.30)\end{array}$ & $\begin{array}{c}8.95 \\
(10.87)\end{array}$ \\
\hline Net wealth excl. home equity $(10,000 \mathrm{E})$ & $\begin{array}{c}6.14 \\
(13.48)\end{array}$ & $\begin{array}{c}6.92 \\
(13.45)\end{array}$ & $\begin{array}{l}14.28 \\
(18.67)\end{array}$ \\
\hline Human wealth $(10,000 \mathrm{E})$ & $\begin{array}{l}98.74 \\
(76.90)\end{array}$ & $\begin{array}{l}90.95 \\
(70.06)\end{array}$ & $\begin{array}{l}114.27 \\
(79.36)\end{array}$ \\
\hline Variance of persistent component of gross income & $\begin{array}{c}0.02 \\
(0.19)\end{array}$ & $\begin{array}{c}0.01 \\
(0.05)\end{array}$ & $\begin{array}{c}0.01 \\
(0.06)\end{array}$ \\
\hline Variance of transitory component of gross income & $\begin{array}{c}0.03 \\
(0.22)\end{array}$ & $\begin{array}{c}0.02 \\
(0.09)\end{array}$ & $\begin{array}{c}0.02 \\
(0.09)\end{array}$ \\
\hline Homeowner & $\begin{array}{c}0.59 \\
(0.49)\end{array}$ & $\begin{array}{c}0.65 \\
(0.48)\end{array}$ & $\begin{array}{c}0.84 \\
(0.37)\end{array}$ \\
\hline Household size & $\begin{array}{c}2.28 \\
(1.23)\end{array}$ & $\begin{array}{c}2.34 \\
(1.25)\end{array}$ & $\begin{array}{c}2.52 \\
(1.27)\end{array}$ \\
\hline Household composition & & & \\
\hline Single or single parent & $\begin{array}{c}0.37 \\
(0.48)\end{array}$ & $\begin{array}{c}0.32 \\
(0.47)\end{array}$ & $\begin{array}{c}0.24 \\
(0.43)\end{array}$ \\
\hline 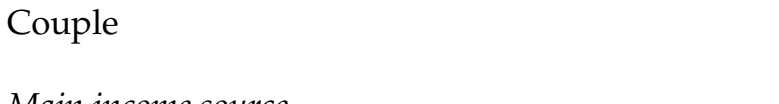 & $\begin{array}{c}0.63 \\
(0.48)\end{array}$ & $\begin{array}{c}0.68 \\
(0.47)\end{array}$ & $\begin{array}{c}0.76 \\
(0.43)\end{array}$ \\
\hline $\begin{array}{l}\text { Main income source } \\
\text { Private sector employment }\end{array}$ & $\begin{array}{c}0.48 \\
(0.50)\end{array}$ & $\begin{array}{c}0.44 \\
(0.50)\end{array}$ & $\begin{array}{c}0.45 \\
(0.50)\end{array}$ \\
\hline Public sector employment & $\begin{array}{c}0.07 \\
(0.26)\end{array}$ & $\begin{array}{c}0.07 \\
(0.25)\end{array}$ & $\begin{array}{c}0.08 \\
(0.27)\end{array}$ \\
\hline Enterprise & $\begin{array}{c}0.11 \\
(0.32)\end{array}$ & $\begin{array}{c}0.11 \\
(0.31)\end{array}$ & $\begin{array}{c}0.15 \\
(0.36)\end{array}$ \\
\hline Wealth & $\begin{array}{c}0.00 \\
(0.05)\end{array}$ & $\begin{array}{c}0.00 \\
(0.05)\end{array}$ & $\begin{array}{c}0.01 \\
(0.08)\end{array}$ \\
\hline Benefits & $\begin{array}{c}0.07 \\
(0.25)\end{array}$ & $\begin{array}{c}0.07 \\
(0.26)\end{array}$ & $\begin{array}{c}0.03 \\
(0.18)\end{array}$ \\
\hline Pension & $\begin{array}{l}0.26 \\
(0.44)\end{array}$ & $\begin{array}{c}0.31 \\
(0.46)\end{array}$ & $\begin{array}{c}0.28 \\
(0.45)\end{array}$ \\
\hline Other or none & $\begin{array}{c}0.01 \\
(0.10)\end{array}$ & $\begin{array}{c}0.00 \\
(0.04)\end{array}$ & $\begin{array}{c}0.00 \\
(0.04)\end{array}$ \\
\hline Instruments & & & \\
\hline Home price index yr of purchase & $\begin{array}{l}74.25 \\
(28.90)\end{array}$ & $\begin{array}{c}63.99 \\
(25.01)\end{array}$ & $\begin{array}{c}64.67 \\
(25.08)\end{array}$ \\
\hline Home price index current yr & $\begin{array}{l}105.62 \\
(5.81)\end{array}$ & $\begin{array}{l}105.72 \\
(5.70)\end{array}$ & $\begin{array}{l}106.06 \\
(5.54)\end{array}$ \\
\hline Observations & 4020047 & 1729510 & 462320 \\
\hline
\end{tabular}




\section{Appendix B Models}

In the equations below $s_{i t}$ is the share of liquid assets held in stocks. $p_{i t}$ is the stock market participation dummy, which equals 1 if $s_{i t}>0$. $H E_{i t}$ denotes the amount of home equity and $M_{i t}$ gives the amount of mortgage outstanding.

\section{B.1 Tobit}

$$
\begin{array}{r}
s_{i t}^{*}=\alpha+\beta_{1} H E_{i t}+\beta_{2} M_{i t}+\gamma \mathbf{X}_{i t}+\epsilon_{i t} \\
s_{i t}=s_{i t}^{*} \text { if } s_{i t}^{*}>0 \\
=0 \quad \text { if } s_{i t}^{*} \leq 0
\end{array}
$$

\section{B.2 2SLS}

$$
\begin{array}{r}
s_{i t}=\alpha+\beta_{1} H E_{i t}+\beta_{2} M_{i t}+\gamma \mathbf{X}_{i t}+\epsilon_{i t} \\
H E_{i t}=\theta_{1}+\delta_{1} Z_{i t}+\xi_{1} \mathbf{X}_{i t}+v_{i t} \\
M_{i t}=\theta_{2}+\delta_{2} Z_{i t}+\xi_{2} \mathbf{X}_{i t}+\eta_{i t}
\end{array}
$$

$Z_{i t}$ is a vector of instruments containing the house price index in the current year and the year of purchase.

\section{B.3 IV Tobit mortgage Tobit}

$$
\begin{aligned}
& s_{i t}^{*}=\alpha+\beta_{1} H E_{i t}+\beta_{2} M_{i t}+\gamma \mathbf{X}_{i t}+\epsilon_{i t} \\
& H E_{i t}=\theta_{1}+\delta_{1} Z_{i t}+\xi_{1} \mathbf{X}_{i t}+v_{i t} \\
& M_{i t}^{*}=\theta_{2}+\delta_{2} Z_{i t}+\xi_{2} \mathbf{X}_{i t}+\eta_{i t} \\
& s_{i t}=s_{i t}^{*} \quad \text { if } \quad s_{i t}^{*}>0 \\
&=0 \quad \text { if } \quad s_{i t}^{*} \leq 0 \\
& M_{i t}=M_{i t}^{*} \quad \text { if } \quad M_{i t}^{*}>0 \\
&=0 \text { if } \quad M_{i t}^{*} \leq 0
\end{aligned}
$$

$Z_{i t}$ is a vector of instruments containing the house price index in the current year and the year of purchase. The error terms $\left(\epsilon_{i t}, v_{i t}, \eta_{i t}\right)$ are assumed to be independent and identically distributed and follow a multivariate normal distribution. 


\section{B.4 IV Tobit mortgage OLS}

$$
\begin{array}{r}
s_{i t}^{*}=\alpha+\beta_{1} H E_{i t}+\beta_{2} M_{i t}+\gamma \mathbf{X}_{i t}+\epsilon_{i t} \\
H E_{i t}=\theta_{1}+\delta_{1} Z_{i t}+\xi_{1} \mathbf{X}_{i t}+v_{i t} \\
M_{i t}=\theta_{2}+\delta_{2} Z_{i t}+\xi_{2} \mathbf{X}_{i t}+\eta_{i t} \\
s_{i t}=s_{i t}^{*} \text { if } s_{i t}^{*}>0 \\
=0 \quad \text { if } s_{i t}^{*} \leq 0
\end{array}
$$

$Z_{i t}$ is a vector of instruments containing the house price index in the current year and the year of purchase. The error terms $\left(\epsilon_{i t}, v_{i t}, \eta_{i t}\right)$ are assumed to be independent and identically distributed and follow a multivariate normal distribution.

\section{B.5 2SLS with selection correction}

$$
\begin{array}{r}
s_{i t}=\alpha+\beta_{1} H E_{i t}+\beta_{2} M_{i t}+\kappa \lambda_{i t}+\gamma \mathbf{X}_{i t}+\epsilon_{i t} \\
H E_{i t}=\theta_{1}+\delta_{1} Z_{i t}+\kappa \lambda_{i t}+\xi_{1} \mathbf{X}_{i t}+v_{i t} \\
M_{i t}=\theta_{2}+\delta_{2} Z_{i t}+\kappa \lambda_{i t}+\xi_{2} \mathbf{X}_{i t}+\eta_{i t}
\end{array}
$$

$Z_{i t}$ is a vector of instruments containing the house price index in the current year and the year of purchase. $\lambda_{i t}$ denotes the inverse Mills ratio, which is calculated from a Probit regression of the stock market participation dummy on the variables in $\mathbf{X}_{i t}$ and the predicted values of the two endogenous regressors.

\section{B.6 Heckman with predicted values of endogenous regres-} sors

$$
\begin{array}{r}
s_{i t}^{*}=\alpha+\beta_{1} \hat{H E} E_{i t}+\beta_{2} \hat{M}_{i t}+\gamma \mathbf{X}_{1 i t}+\epsilon_{1 i t} \\
p_{i t}^{*}=\alpha+\beta_{1} \hat{H E} E_{i t}+\beta_{2} \hat{M}_{i t}+\gamma \mathbf{X}_{2 i t}+\epsilon_{2 i t} \\
s_{i t}=s_{i t}^{*}, p_{i t}=1 \quad \text { if } \quad p_{i t}^{*}>0 \\
s_{i t}=\text { not observed, } p_{i t}=0 \text { if } \quad p_{i t}^{*} \leq 0 \\
\epsilon_{1 i t} \sim N(0,1), \epsilon_{2 i t} \sim N\left(0, \sigma^{2}\right), \operatorname{corr}\left(\epsilon_{1 i t}, \epsilon_{2 i t}\right)=\rho
\end{array}
$$

$\mathbf{X}_{1 i t}$ is a set of control variables, $\mathbf{X}_{2 i t}$ includes both the variables in $\mathbf{X}_{1 i t}$ and the net wealth excluding home equity and the level of human wealth. $\hat{H E} E_{i t}$ and $\hat{M}_{i t}$ denote the values predicted from OLS regressions of home equity and mortgage debt on the instruments $Z_{i t}$ and the controls in $\mathbf{X}_{2 i t}$. 


\section{Appendix C Lifetime income and its variance}

We calculate the present value of lifetime income of the household head as follows, similar to Fagereng et al. (2013). We divide the sample into ten household income deciles. For each income decile $d$, we run the following regression

$$
Y_{i a t c}=\alpha_{c}+\beta_{d} X_{i t c}+\gamma_{t}+\theta_{a}+\epsilon_{i a t c},
$$

where $Y_{\text {iatd }}$ is the household head's gross income in year $t, \alpha_{d}$ is a constant, $X_{i t c}$ a set of demographic controls that includes household size, an indicator if the household head is married and an indicator if the household head is part of a couple, and $\theta_{a}$ is a full set of age dummies. We then predict the household head's future income at different ages $a+1 \leq k \leq$ 99 as

$$
\hat{Y}_{i k t c}=\alpha_{c}+\beta_{d} X_{i t c}+\gamma_{t}+\theta_{k}+\epsilon_{i a t c}
$$

From this we calculate the household head's discounted lifetime income as

$$
\sum_{k=a+1}^{k=99} \frac{\hat{Y}_{i k t c}}{(1+r)^{k-(a+1)}} P(k \mid a),
$$

where $P(k \mid a)$ is the probability of surviving until age $k$ conditional on having reached age $a \sqrt{18}$ and $r=0.03$.

To determine the variance in yearly income and to decompose this variance into a transitory and permanent component, we take the approach of (Carroll \& Simwick, 1997). They present a model in which the log of income $y_{t}$ has a permanent component $p_{t}$ and a transitory part $\epsilon_{t}$. The permanent term equals its lagged value $p_{t-1}$ plus an innovation $\eta_{t}$ (for ease of exposition, we omit predictable trends from age or other characteristics). Then the $d$-year income difference equals

$$
r_{d}=y_{t+d}-y_{t}=p_{t+d}-p_{t}+\epsilon_{t+d}-\epsilon_{t},
$$

which we can rewrite as

$$
r_{d}=\eta_{t+1}+\eta_{t+2}+\ldots+\eta_{t+d}+\epsilon_{t+d}-\epsilon_{t} .
$$

If all $\eta_{t}$ and $\epsilon_{t}$ are independently and identically distributed with variance $\sigma_{\eta}^{2}$ and $\sigma_{\epsilon}^{2}$, respectively, we have

$$
\operatorname{var}\left(r_{d}\right)=d \sigma_{\eta}^{2}+2 \sigma_{\epsilon}^{2}
$$

\footnotetext{
${ }^{18}$ For this, we use unisex survival tables for 2010 from Statistics Netherlands.
} 
Carroll \& Simwick (1997) argue that we can estimate var $\left(r_{d}\right)$ with $v_{d}=r_{d}^{2}$ and that any two $v_{d}$ of different length suffice to identify the householdspecific $\sigma_{\eta}^{2}$ and $\sigma_{\epsilon}^{2}$. Since we have seven sample years, we can calculate up to $\frac{7 * 6}{2}=21 v_{d}$ per household. As in Fagereng et al. (2013), we first run a regression of the log gross income of the household head on the same characteristics as in (10):

$$
\log \left(Y_{\text {iatc }}\right)=\alpha_{c}+\beta_{d} X_{i t c}+\gamma_{t}+\theta_{a}+\epsilon_{\text {iatc }} .
$$

We then obtain the household-specific $\sigma_{\eta}^{2}$ and $\sigma_{\epsilon}^{2}$ by regressing the up to 21 $d$-year-ahead prediction errors $\left(\epsilon_{i(a+d)(t+d) c}-\epsilon_{\text {iatc }}\right)^{2}$ on $d$ and a constant. As we show in Table 2, the transitory variance is larger than the permanent variance in our sample. The magnitude of the permanent and transitory components are comparable to estimates for Norway in Fagereng et al. (2013). 


\section{Appendix D Figures}

Figure 1: COROP house price index 2011 (2005 = 100)

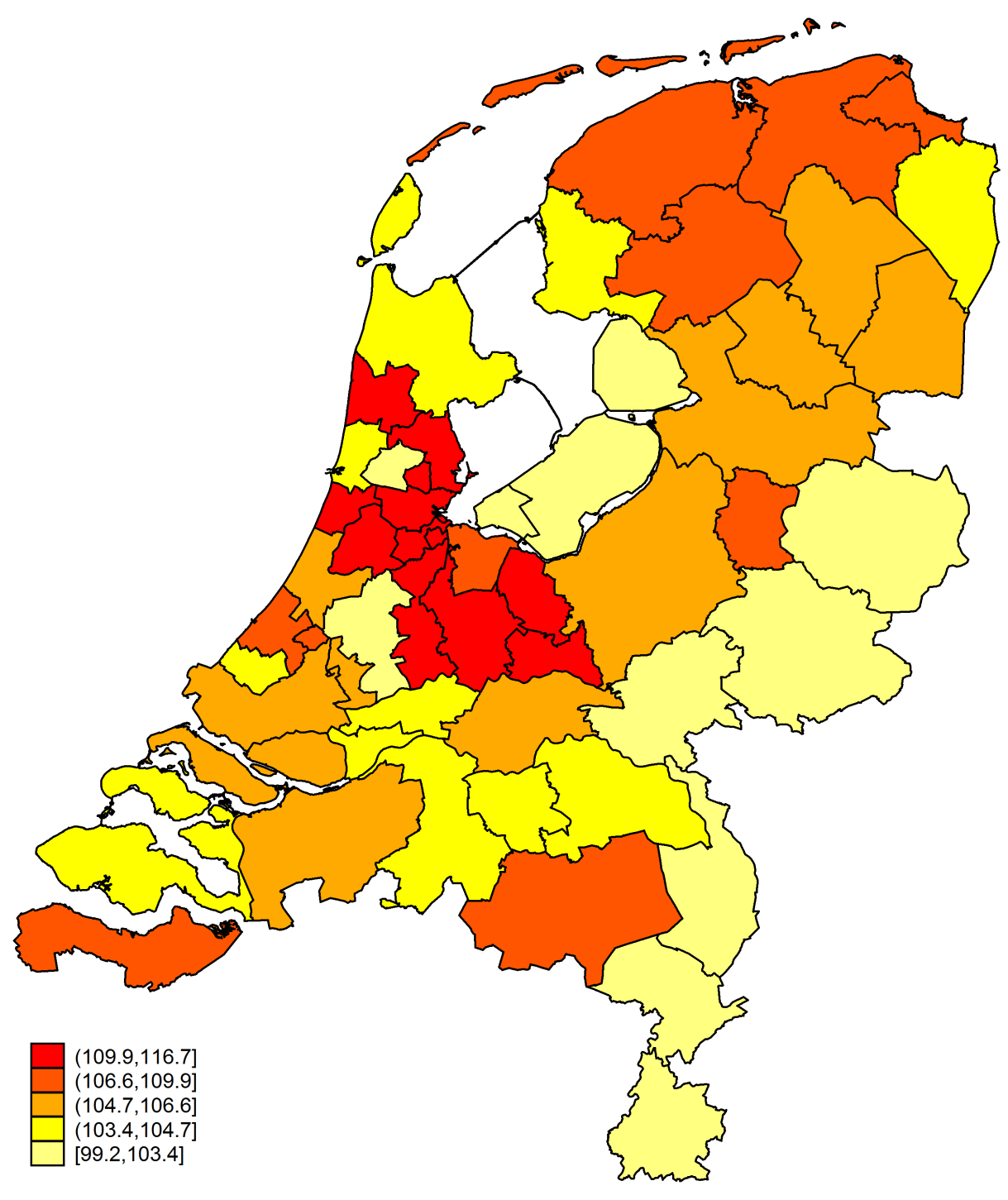


Figure 2: Stock market participation over the life cycle

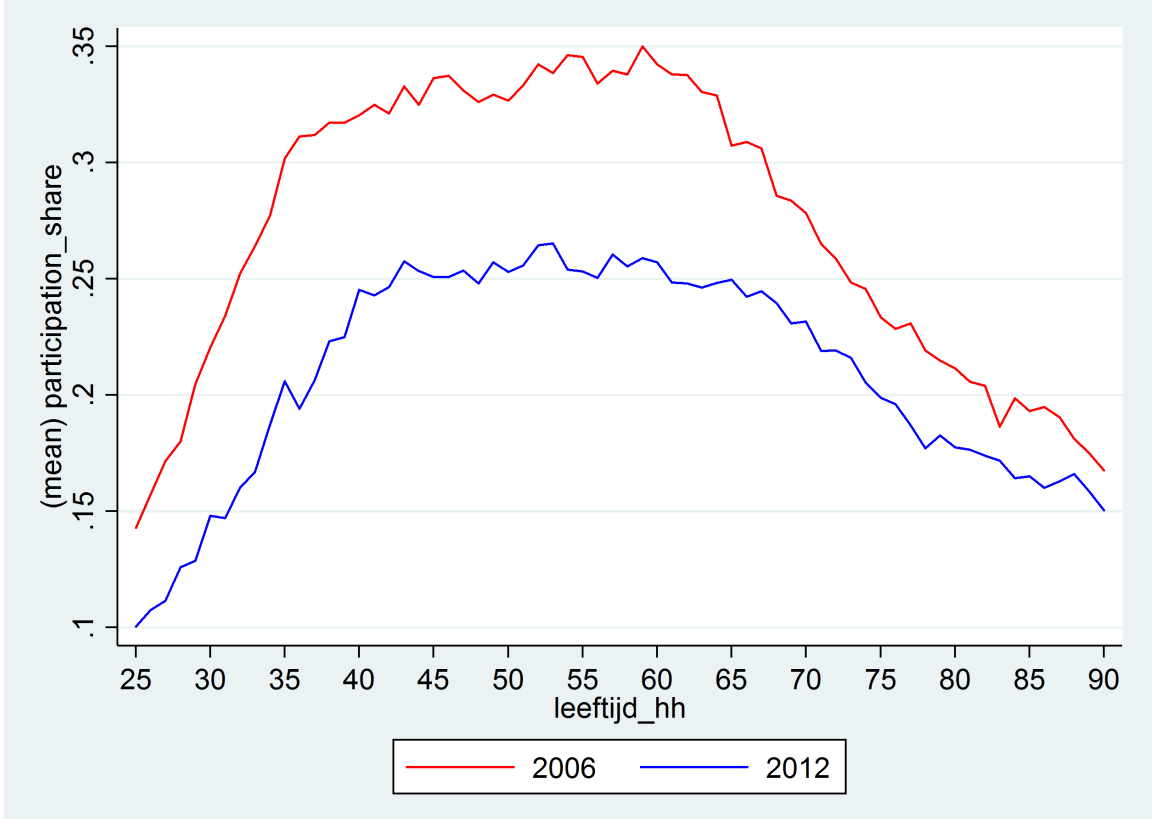

Figure 3: Stock market participation over the life cycle: owners and renters

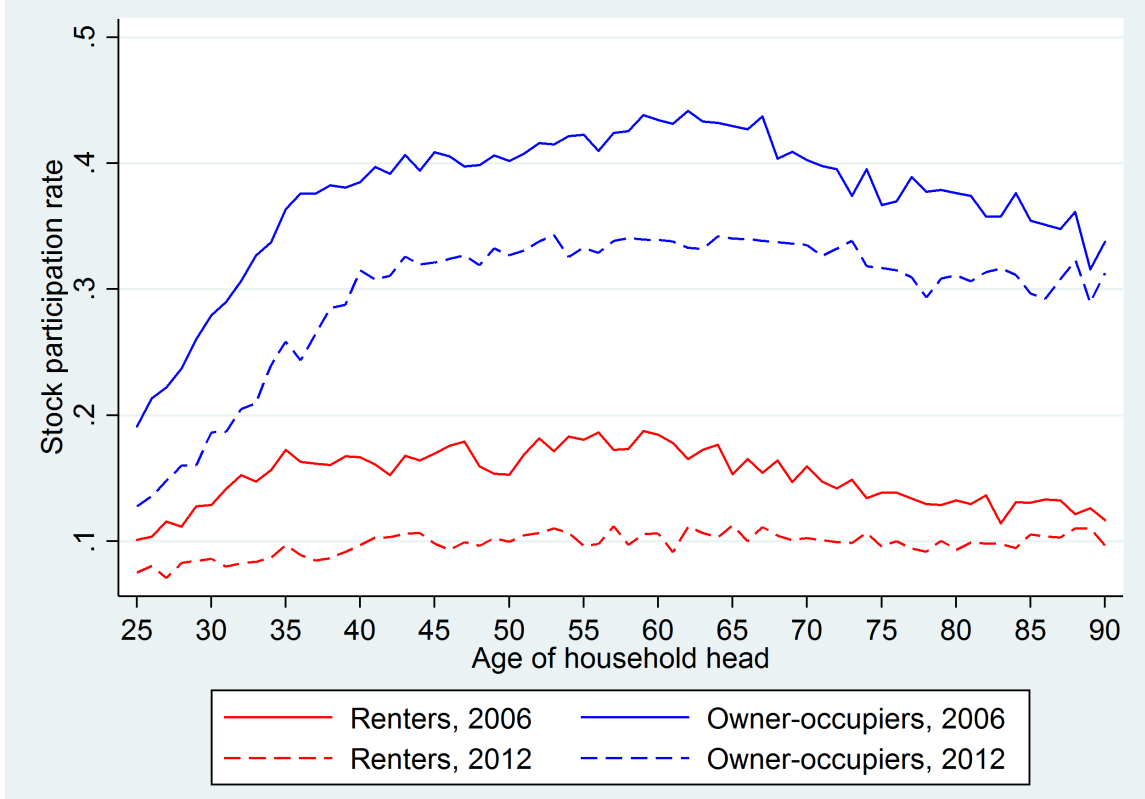


Figure 4: Stock market participation for different birth year cohorts

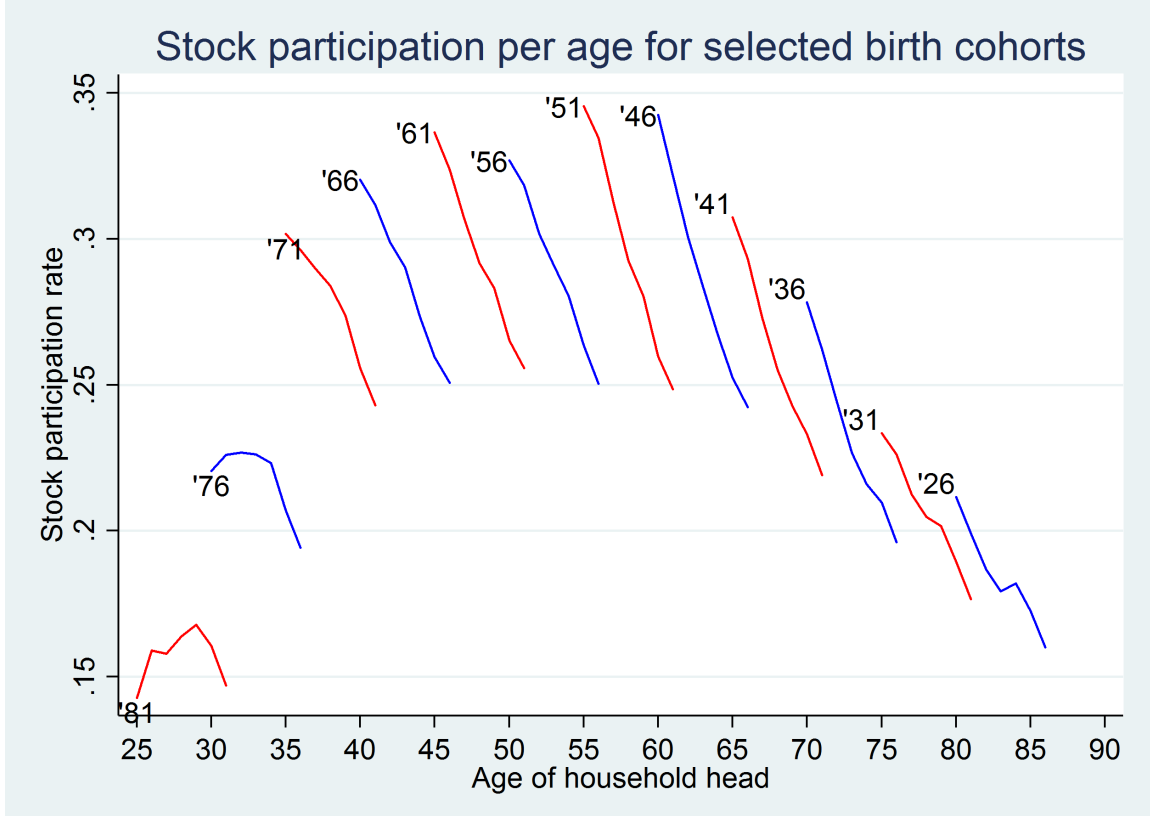

Figure 5: Home equity over the life cycle

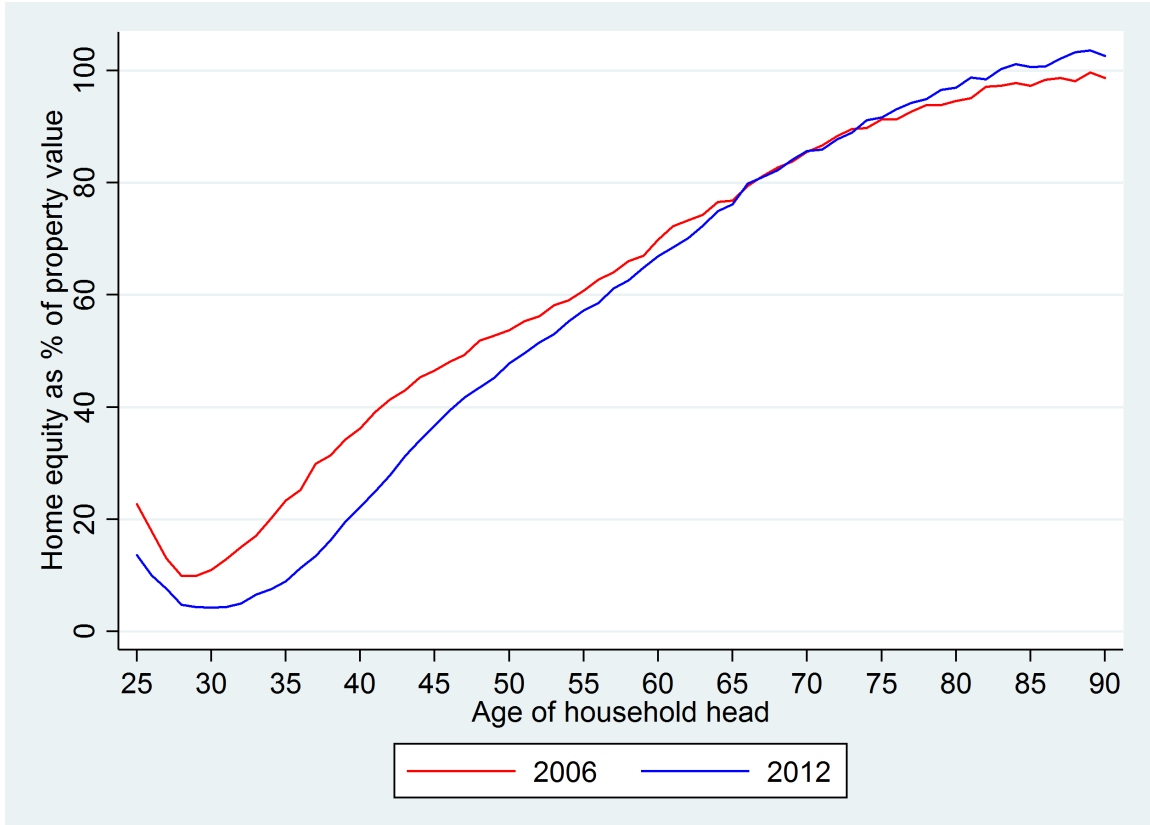


Figure 6: Home equity for different birth year cohorts

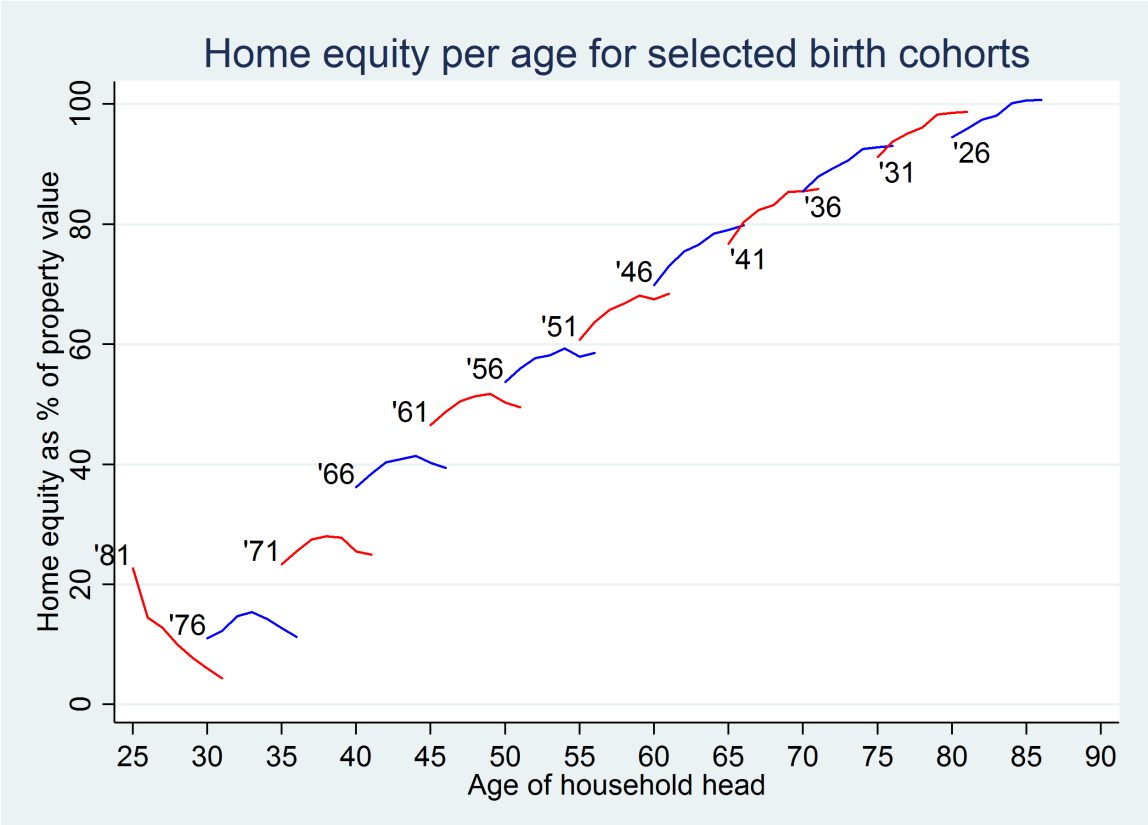

Figure 7: Home equity and risky share for different age categories
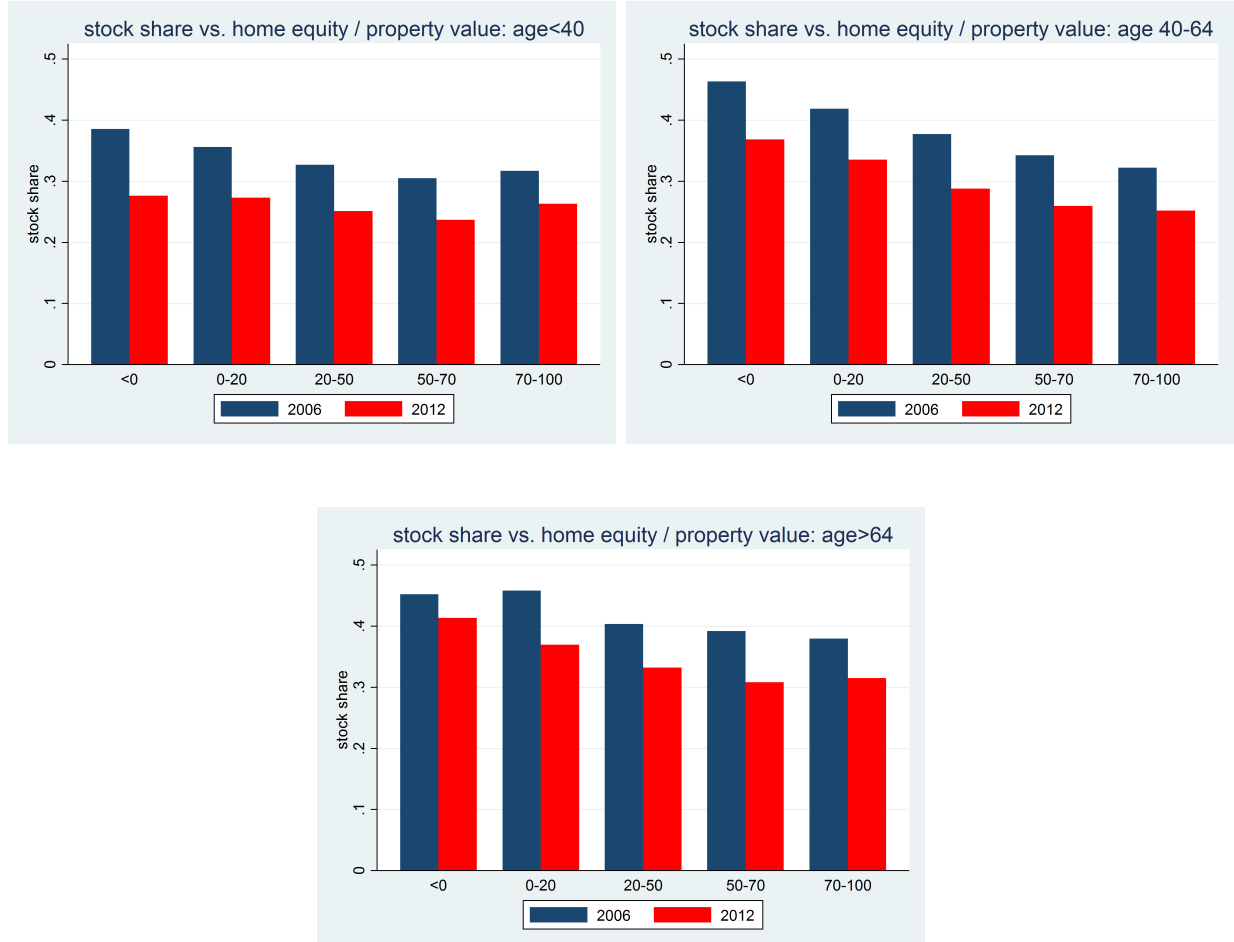


\section{Appendix E Results}

Table 3: Tobit and IV Tobit models

\begin{tabular}{lccc}
\hline & Tobit & IVTobit-M Tobit & IVTobit-M OLS \\
\hline Stock share & & & \\
Home equity & $0.0041^{* * *}$ & -0.0120 & 0.0292 \\
& $(0.0005)$ & $(0.0115)$ & $(0.0243)$ \\
Outstanding mortgage & $0.0063^{* * *}$ & 0.0006 & 0.0757 \\
& $(0.0007)$ & $(0.0016)$ & $(0.0527)$ \\
Net wealth excl. home equity & $0.0078^{* * *}$ & $0.0101^{* * *}$ & 0.0023 \\
& $(0.0002)$ & $(0.0015)$ & $(0.0047)$ \\
Human wealth & $0.0005^{* * *}$ & $0.0007^{* * *}$ & -0.0030 \\
& $(0.0001)$ & $(0.0001)$ & $(0.0026)$ \\
\hline Home equity (first stage) & & & \\
Home price index yr of purchase & & $-0.1196^{* * *}$ & $-0.1150^{* * *}$ \\
& & $(0.0269)$ & $(0.0272)$ \\
Home price index current yr & & $0.0909^{* *}$ & $0.1000^{* * *}$ \\
Net wealth excl. home equity & & $(0.0312)$ & $(0.0277)$ \\
& & $0.1269^{* * *}$ & $0.1268^{* * *}$ \\
Human wealth & & $(0.0073)$ & $(0.0073)$ \\
& & -0.0013 & -0.0013 \\
& & $(0.0013)$ & $(0.0013)$ \\
\hline Outstanding mortgage (first stage) & & & \\
Home price index yr of purchase & & $0.0683^{*}$ & $0.0753^{* *}$ \\
Home price index current yr & & $(0.0274)$ & $(0.0236)$ \\
Net wealth excl. home equity & & -0.0312 & -0.0329 \\
& & $(0.0294)$ & $(0.0252)$ \\
Human wealth & & $0.0605^{* * *}$ & $0.0331^{* * *}$ \\
& & $(0.0075)$ & $(0.0065)$ \\
Education FE & & $0.0511^{* * *}$ & $0.0499^{* * *}$ \\
Regional FE & & $(0.0016)$ & $(0.0013)$ \\
Sample & & Yes & Yes \\
& & COROP & COROP \\
\hline
\end{tabular}

Note: Asterisks indicate significance at the $5 \%\left({ }^{*}\right), 1 \%\left({ }^{* *}\right)$ and $0.1 \%\left({ }^{* * *}\right)$ level. Standard errors (in parentheses) are clustered at the household level. Controls: year dummies, year-of-purchase dummies, age categories, current and year-of-purchase unemployment level, transitory and persistent variance of income, main income source, household size, and a single-adult household indicator. We control for cohort effects by including the average stock return in the years when the household head was 18-25. 
Table 4: IV and Heckman estimates

\begin{tabular}{|c|c|c|c|c|}
\hline & 2SLS & 2SLS IMR & Heckman M-OLS & Heckman M-Tob \\
\hline \multicolumn{5}{|l|}{ main } \\
\hline Home equity & $\begin{array}{c}0.0047 \\
(0.0040)\end{array}$ & $\begin{array}{c}0.0387 \\
(0.0586)\end{array}$ & $\begin{array}{c}0.0235^{* * *} \\
(0.0010)\end{array}$ & $\begin{array}{c}0.0220^{* * *} \\
(0.0008)\end{array}$ \\
\hline \multirow[t]{2}{*}{ Outstanding mortgage } & 0.0207 & 0.0915 & -0.0001 & $-0.0014^{* * *}$ \\
\hline & $(0.0119)$ & $(0.1408)$ & $(0.0004)$ & $(0.0003)$ \\
\hline Net wealth excl. home equity & $\begin{array}{c}0.0015 \\
(0.0009)\end{array}$ & & & \\
\hline Human wealth & $\begin{array}{l}-0.0008 \\
(0.0006)\end{array}$ & & & \\
\hline Inverse Mills ratio & & $\begin{array}{c}0.9256 \\
(1.3386)\end{array}$ & $\begin{array}{c}0.1967^{* * *} \\
(0.0093)\end{array}$ & $\begin{array}{c}0.1779^{* * *} \\
(0.0065)\end{array}$ \\
\hline \multicolumn{5}{|l|}{ Home equity (first stage) } \\
\hline Home price index yr of purchase & $\begin{array}{c}-0.1165^{* * *} \\
(0.0148)\end{array}$ & $\begin{array}{c}-0.2037^{* * *} \\
(0.0280)\end{array}$ & $\begin{array}{c}-0.1168^{* * *} \\
(0.0148)\end{array}$ & $\begin{array}{c}-0.1168^{* * *} \\
(0.0148)\end{array}$ \\
\hline Home price index current yr & $\begin{array}{c}0.0809^{* * *} \\
(0.0115)\end{array}$ & $\begin{array}{c}0.1045^{* * *} \\
(0.0171)\end{array}$ & $\begin{array}{c}0.0802^{* * *} \\
(0.0114)\end{array}$ & $\begin{array}{c}0.0802^{* * *} \\
(0.0114)\end{array}$ \\
\hline Net wealth excl. home equity & $\begin{array}{c}0.1233^{* * *} \\
(0.0036)\end{array}$ & & $\begin{array}{c}0.1220^{* * *} \\
(0.0036)\end{array}$ & $\begin{array}{c}0.1220^{* * *} \\
(0.0036)\end{array}$ \\
\hline Human wealth & $\begin{array}{c}0.0003 \\
(0.0006)\end{array}$ & & $\begin{array}{c}0.0004 \\
(0.0006)\end{array}$ & $\begin{array}{c}0.0004 \\
(0.0006)\end{array}$ \\
\hline \multicolumn{2}{|l|}{ Inverse Mills ratio } & $\begin{array}{c}-6.6517^{* * *} \\
(0.2476)\end{array}$ & & \\
\hline \multicolumn{5}{|l|}{ Outstanding mortgage (first stage) } \\
\hline Home price index yr of purchase & $\begin{array}{c}0.0551^{* * *} \\
(0.0131)\end{array}$ & $\begin{array}{c}0.0942^{* * *} \\
(0.0257)\end{array}$ & $\begin{array}{c}0.0551^{* * *} \\
(0.0131)\end{array}$ & $\begin{array}{c}0.0620^{* * *} \\
(0.0160)\end{array}$ \\
\hline Home price index current yr & $\begin{array}{c}-0.0089 \\
(0.0110)\end{array}$ & $\begin{array}{c}-0.0367^{*} \\
(0.0160)\end{array}$ & $\begin{array}{c}-0.0089 \\
(0.0110)\end{array}$ & $\begin{array}{c}-0.0247 \\
(0.0136)\end{array}$ \\
\hline Net wealth excl. home equity & $\begin{array}{c}0.0391^{* * *} \\
(0.0033)\end{array}$ & & $\begin{array}{c}0.0391^{* * *} \\
(0.0033)\end{array}$ & $\begin{array}{c}0.0869^{* * *} \\
(0.0081)\end{array}$ \\
\hline Human wealth & $\begin{array}{c}0.0468^{* * *} \\
(0.0006)\end{array}$ & & $\begin{array}{c}0.0468^{* * *} \\
(0.0006)\end{array}$ & $\begin{array}{c}0.0462^{* * *} \\
(0.0006)\end{array}$ \\
\hline Inverse Mills ratio & & $\begin{array}{c}-6.7453^{* * *} \\
(0.2331)\end{array}$ & & \\
\hline \multicolumn{5}{|l|}{ Stock indicator } \\
\hline Home equity & & & $\begin{array}{c}0.0225 \\
(0.0204)\end{array}$ & $\begin{array}{c}-0.0218^{* *} \\
(0.0075)\end{array}$ \\
\hline Outstanding mortgage & & & $\begin{array}{l}0.0984^{*} \\
(0.0491)\end{array}$ & $\begin{array}{c}-0.0208^{* * *} \\
(0.0016)\end{array}$ \\
\hline Net wealth excl. home equity & & & $\begin{array}{c}0.0200^{* * *} \\
(0.0043)\end{array}$ & $\begin{array}{c}0.0301^{* * *} \\
(0.0009)\end{array}$ \\
\hline Human wealth & & & $\begin{array}{l}-0.0019 \\
(0.0023)\end{array}$ & $\begin{array}{c}0.0034^{* * *} \\
(0.0001)\end{array}$ \\
\hline Education FE & Yes & Yes & Yes & Yes \\
\hline Regional FE & COROP & COROP & COROP & COROP \\
\hline Sample & Full & Full & Full & Full \\
\hline $\mathrm{N}$ & 537006 & 169635 & 537006 & 537006 \\
\hline Hansen J-stat. & 0.0000 & 0.0000 & & \\
\hline Kleibergen-Paap rk LM stat & $5.7484^{*}$ & 0.4317 & & \\
\hline Cragg-Donald Wald F stat & $5.75^{* * *}$ & 0.27 & & \\
\hline
\end{tabular}

Note: Asterisks indicate significance at the $5 \%\left({ }^{*}\right), 1 \%\left({ }^{* *}\right)$ and $0.1 \%\left({ }^{* * *}\right)$ level. Standard errors in parentheses. Heckman models are estimated using the twostep estimator. The twostep estimator does not allow to cluster standard errors, therefore results should be interpreted with caution. The weak instrument statistic should be interpreted with caution as it does not allow for clustering of the standard errors. Controls: year dummies, year-of-purchase dummies, age categories, cuaarrent and year-of-purchase unemployment level, transitory and persistent variance of income, main income source, household size, and a single-adult household indicator. We control for cohort effects by including the average stock return in the years when the household head was $18-25$. 
Table 5: Tobit and IV Tobit models for home owners

\begin{tabular}{lccc}
\hline & Tobit & IVTobit-M Tobit & IVTobit-M OLS \\
\hline Stock share & & & \\
Home equity & $0.0041^{* * *}$ & -0.0036 & 0.0289 \\
& $(0.0004)$ & $(0.0068)$ & $(0.0263)$ \\
Outstanding mortgage & $0.0062^{* * *}$ & $0.0055^{*}$ & 0.0755 \\
& $(0.0007)$ & $(0.0027)$ & $(0.0602)$ \\
Net wealth excl. home equity & $0.0083^{* * *}$ & $0.0096^{* * *}$ & 0.0054 \\
& $(0.0003)$ & $(0.0012)$ & $(0.0034)$ \\
Human wealth & $0.0003^{* *}$ & 0.0003 & -0.0035 \\
& $(0.0001)$ & $(0.0002)$ & $(0.0033)$ \\
\hline Home equity (first stage) & & & \\
Home price index yr of purchase & & $-0.1921^{* * *}$ & $-0.1872^{* * *}$ \\
& & $(0.0321)$ & $(0.0315)$ \\
Home price index current yr & & $0.1648^{* * *}$ & $0.1741^{* * *}$ \\
& & $(0.0391)$ & $(0.0376)$ \\
Net wealth excl. home equity & & $0.1648^{* * *}$ & $0.1648^{* * *}$ \\
& & $(0.0109)$ & $(0.0109)$ \\
Human wealth & & -0.0001 & -0.0001 \\
& & $(0.0024)$ & $(0.0024)$ \\
\hline Outstanding mortgage (first stage) & & & \\
Home price index yr of purchase & & $0.1100^{* * *}$ & $0.1040^{* * *}$ \\
& & $(0.0294)$ & $(0.0271)$ \\
Home price index current yr & & -0.0480 & -0.0506 \\
Net wealth excl. home equity & & $(0.0377)$ & $(0.0365)$ \\
& & $-0.0286^{*}$ & -0.0173 \\
Human wealth & & $(0.0112)$ & $(0.0100)$ \\
& & $0.0533^{* * *}$ & $0.0539^{* * *}$ \\
Education FE & & $(0.0022)$ & $(0.0022)$ \\
Regional FE & & Yes & Yes \\
Sample & COROP & COROP & COROP \\
& & Owners & Owners \\
& & 110848 & 110848 \\
\hline
\end{tabular}

Note: Asterisks indicate significance at the $5 \%\left({ }^{*}\right), 1 \%\left(^{* *}\right)$ and $0.1 \%\left({ }^{* * *}\right)$ level. Standard errors (in parentheses) are clustered at the household level. Controls: year dummies, year-of-purchase dummies, age categories, current and year-of-purchase unemployment level, transitory and persistent variance of income, main income source, household size, and a single-adult household indicator. We control for cohort effects by including the average stock return in the years when the household head was 18-25. 
Table 6: Tobit and IV Tobit models for households below 60

\begin{tabular}{|c|c|c|c|}
\hline & Tobit & IVTobit-M Tobit & IVTobit-M OLS \\
\hline \multicolumn{4}{|l|}{ Stock share } \\
\hline \multirow[t]{2}{*}{ Home equity } & $0.0043^{* * *}$ & -0.0174 & 0.0414 \\
\hline & $(0.0005)$ & $(0.0158)$ & $(0.0444)$ \\
\hline \multirow[t]{2}{*}{ Outstanding mortgage } & $0.0064^{* * *}$ & -0.0007 & 0.1062 \\
\hline & $(0.0007)$ & $(0.0019)$ & $(0.0899)$ \\
\hline \multirow[t]{2}{*}{ Net wealth excl. home equity } & $0.0075^{* * *}$ & $0.0103^{* * *}$ & -0.0011 \\
\hline & $(0.0002)$ & $(0.0018)$ & $(0.0088)$ \\
\hline \multirow[t]{2}{*}{ Human wealth } & $0.0005^{* * *}$ & $0.0008^{* * *}$ & -0.0044 \\
\hline & $(0.0001)$ & $(0.0001)$ & $(0.0044)$ \\
\hline \multicolumn{4}{|l|}{ Home equity (first stage) } \\
\hline \multirow[t]{2}{*}{ Home price index yr of purchase } & & $-0.1043^{* * *}$ & $-0.0942^{* * *}$ \\
\hline & & $(0.0275)$ & $(0.0274)$ \\
\hline \multirow[t]{2}{*}{ Home price index current yr } & & $0.0871^{*}$ & $0.1055^{* * *}$ \\
\hline & & $(0.0401)$ & $(0.0311)$ \\
\hline \multirow[t]{2}{*}{ Net wealth excl. home equity } & & $0.1123^{* * *}$ & $0.1123^{* * *}$ \\
\hline & & $(0.0076)$ & $(0.0076)$ \\
\hline \multirow[t]{2}{*}{ Human wealth } & & 0.0009 & 0.0009 \\
\hline & & $(0.0013)$ & $(0.0013)$ \\
\hline \multicolumn{4}{|l|}{ Outstanding mortgage (first stage) } \\
\hline \multirow[t]{2}{*}{ Home price index yr of purchase } & & $0.0688^{*}$ & $0.0659^{* *}$ \\
\hline & & $(0.0292)$ & $(0.0253)$ \\
\hline \multirow[t]{2}{*}{ Home price index current yr } & & -0.0248 & -0.0342 \\
\hline & & $(0.0350)$ & $(0.0303)$ \\
\hline \multirow[t]{2}{*}{ Net wealth excl. home equity } & & $0.0745^{* * *}$ & $0.0441^{* * *}$ \\
\hline & & $(0.0083)$ & $(0.0074)$ \\
\hline \multirow[t]{2}{*}{ Human wealth } & & $0.0493^{* * *}$ & $0.0485^{* * *}$ \\
\hline & & $(0.0015)$ & $(0.0014)$ \\
\hline Education FE & Yes & Yes & Yes \\
\hline Regional FE & COROP & COROP & COROP \\
\hline Sample & 60 and younger & 60 and younger & 60 and younger \\
\hline $\mathrm{N}^{1}$ & 119768 & 120168 & 120168 \\
\hline
\end{tabular}

Note: Asterisks indicate significance at the $5 \%\left(^{*}\right), 1 \%\left({ }^{* *}\right)$ and $0.1 \%\left({ }^{* *}\right)$ level. Standard errors (in parentheses) are clustered at the household level. Controls: year dummies, year-of-purchase dummies, age categories, current and year-of-purchase unemployment level, transitory and persistent variance of income, main income source, household size, and a single-adult household indicator. We control for cohort effects by including the average stock return in the years when the household head was 18-25. 